\title{
Identifying Challenging Barriers to Farmers' Adaptation to Climate Change: A Case of Leribe District, Lesotho
}

\section{Tsepang Clementine Mofolo* and Kheleli Mareabetsoe Rethabile}

\author{
UN Environment-Tongji Institute of Environment for Sustainable Development, \\ Tongji University, Shanghai 200092, China.
}

*Corresponding author details: Tsepang Clementine Mofolo; tsepangmofolo13@gmail.com

\begin{abstract}
Climate change has become a global issue that most if not all countries around the world are tackling. Its impacts cut across different sectors, but for less developed countries like Lesotho, agriculture is a sector that is being affected the most. Lesotho depends on rainfed agriculture, mostly for subsistence and in part for commercial purposes as a source of income. Research in Lesotho has focused more on the implications of climate change on environmental processes, and less attention has been directed towards farmers as producers of food in an industry that provides livelihoods to over $70 \%$ of its population. The first approach this article takes is to identify the intent and decision of farmers to adapt to climate change and the barriers that affect these decisions are explored. In identifying challenging barriers to farmers' adaptation to climate change adaptation, the study was carried out in Leribe district, one of the 10 districts in Lesotho because it is known as the food basket of the country due to its high potential arable land. 138 farmers were purposively sampled to carry out the research, which was conducted using questionnaires administered through face-to-face interviews. From the study, perceptions of farmers that rainfall intensity, duration and frequency have decreased, and that temperatures have become extremely high were recorded. This, according to farmers, led to impacts of water shortages, increase in frequency of droughts among other impacts. Farmers have adopted measures to minimize these impacts. The intention of farmers to adapt to climate change amidst the impacts exists amongst farmers. The study therefore aims to identify the potentially challenging barriers to farmers' adaptation to climate change in Leribe. The conclusions drawn from the study are that in the sense of climate change impacts, agricultural productivity reduced, and seasonal food shortages prevailed. Lesotho's capacity to grow its own food has dwindled dramatically. The food security policy must lay out plans to boost food production, and there must be cross-sector partnerships to provide necessary assistance for the lowest and most vulnerable farmers at both district and national levels.
\end{abstract}

Keywords: awareness of climate change; barriers to adaptation; intention to adapt; leribe; perceptions of farmers

\section{INTRODUCTION}

Agriculture is a practice that is recognized as a significant source of income for 60-70 percent of Lesotho's population [1]. Due to a number of causes, including climate change and all of its consequences, this sector has been characterized by poor and diminishing crop yields [2]. Maize, sorghum, beans, and peas are the main crops cultivated in Lesotho. Maize is a staple crop in Lesotho, accounting for 44.4 percent of the local diet, with sorghum, beans, and peas following closely behind [3]. The area under cultivation of these crops decreased from 450, 000 hectares in 1960 to 300,500 hectares in 2006/2007, a little more than 150,000 hectares [4]. Lesotho has seen a lot of food shortages in recent years due to changing weather conditions. This is due to the fact that agriculture in Lesotho is weather and temperature dependent [5]. This means that changes in rainfall and temperature are expected to influence agriculture. Droughts and recurrent dry spells have resulted in poor crop yields in some parts of Southern Africa, including Lesotho, due to rainfall deficits [6]. The low crop yields have also worsened due to increases in temperatures ranging from $2-4^{\circ} \mathrm{C}$ [7].
In Lesotho, the prevalence of erratic climate conditions has restricted the cultivable region and length of seasons, limiting possible crop production. Long periods of drought have resulted in poor rainfall and reduced water tables, depriving crops and plants with shallow root systems of water [8].

\section{Agriculture}

Agriculture in the Leribe district is similarly reliant on rainfall, and irrigation activities are currently limited to a few semi-commercial farmers. Most of the irrigation systems are no longer in use. Farmers in rural areas grow a variety of crops as main crops, including maize, wheat, sorghum, beans, and green peas. Rape, spinach, green pepper, carrots, beetroot, tomatoes, potatoes, radish, pumpkin, onion, watermelon, are some of the additional crops they develop. These are secondary since they are not intended to be a primary source of nutrition. According to LVAC (Lesotho Vulnerability Assessment Committee), cereal demand in Leribe has decreased by ten percent [9]. 
Sheep, goats, donkeys, pigs, horses, poultry, and typical chickens are among the livestock reared by farmers in Leribe's rural area. In the agricultural year 2004/05, there were approximately 98564 cattle, 10670 sheep, 72468 goats, and 6750 pigs [10]. According to livestock census data, the number of goats and sheep has decreased by $9 \%$ nationally, while cattle has decreased by $25 \%$. [11]. Because of the seasons, livestock in Lesotho is homestead for half of the year. Lesotho's Ministry of Agriculture and Food Security is educating farmers on how to take care of their livestock and crops through their District Agricultural Offices (DAO). Non-Governmental Organizations (NGO's) such as RSDA (Rural Self-help Development Association) have forums in districts where they can form alliances and work with DAOs to provide continuous support to farmers [12]. Considering this literature, the study was conducted in Leribe with the purpose of identifying challenging barriers to farmers' adaptation to climate change in that area.

\section{MATERIALS AND METHODS}

\section{Study area - Topography and demography}

The research area of the Leribe district is in Lesotho's northern region. It is Lesotho's second largest district, with industrial and administrative towns as well as several rural communities clustered in villages. It is split into eleven constituencies, also known as city councils. Leribe has nine district councils and two city councils namely Hlotse and Maputsoe. The rural populations in this study region have common features in that they are both Basotho, with Sesotho as their first language and English as their second. The district of Leribe has a total population of 337,521 [13]. According to agricultural reports, in Leribe, an estimated $8 \%$ of 21,082 people $(3,613$ households $)$ are at risk of not meeting their minimum food and non-food needs, revealing that this demographic includes the incredibly disadvantaged, who make up approximately $49 \%$ of the district's population [11].

\section{Climate}

The average elevation of the research area is 1600 meters above sea level. Summers are hot, and winters are brief, chilly, and dry. From November to March, the warm season lasts just four months, with highs of $35^{\circ} \mathrm{C}$. The monthly rainfall in Leribe varies greatly depending on the season. All October and April, the rainy season lasts for just 6 months. Most farmers have rain-fed crop fields, and only a few grow vegetables where irrigation is available. Croplands and grassland used for communal grazing occupy most of the Leribe area. Water scarcity is now a major issue, as farmers primarily practice dryland farming, resulting in low yield, especially during El Nino seasons.

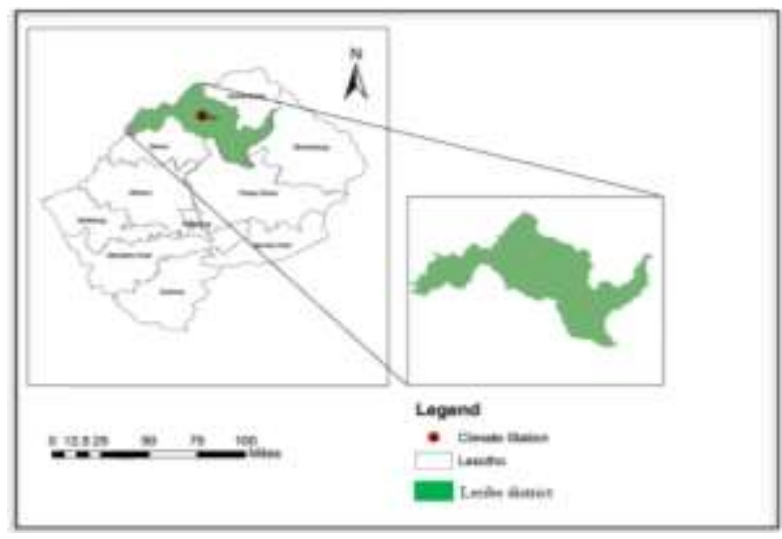

FIGURE 1: Study area of Leribe district

\section{DATA COLLECTION AND SAMPLING}

In Leribe, data was gathered using a quantitative method. A total of 138 farmers were chosen at random to take part in the survey. This sampling approach was chosen because it is said to be the most effective way to obtain personal impressions and opinions from the subject audience [14]. Questionnaires were used to gather results, which were sent out during face-to-face interviews. Farmers were asked about their knowledge of climate change, as well as the increases in temperature, duration, severity, and frequency of rainfall, to figure out what influences were preventing them from responding to climate change. The factors that farmers viewed as obstacles to their climate change adaptation process were the focus of the interviews. Participants were able to explore their interpretations of the society in which they work and articulate how they see things from their own point of view as a result of the interviews [15].

\section{Data entry and coding}

The information gathered from the farmers was entered into Excel and coded. During data processing, data coding entailed assigning a numeric number to answers provided by respondents. The majority of the questions in the survey were binary, with only positive or negative answers. Data was exported to statistical packaging for social sciences (SPSS) for analysis after data entry and coding.

\section{Data analysis}

In this research, descriptive analysis was used, which is analysis of "counting the number of times some elements of the study issue appear in the data and comparing them to other elements" [16]. SPSS version 25 was used for data analysis in the study. After the program had completed the study, the results were displayed using descriptive numbers, frequencies, and bar charts as outputs. The discussion and explanation of the results came after the review of the results obtained.

\section{RESULTS AND DISCUSSIONS}

A structured layout of charts is used to show the findings and interpretation of the data obtained from farmers in Leribe. The study's aim is to find difficult obstacles to climate change adaptation in Leribe. First the study establishes the awareness of farmers to climate change, and the changes they have observed regarding temperature and rainfall, on which their agriculture depends.

\section{Farmers awareness to climate change}

In figure 2, the effects of farmers' climate change awareness in Leribe are presented. When asked if they were aware of climate change, 92 percent of farmers said they were, while the remaining 8 percent said they were not. The findings in Leribe are close to those of a survey in Nigeria, which found that 96 percent of farmers were aware of climate change, compared to just 4 percent who were not [17]. Climate change understanding can be due to the origins of climate data, as well as its dissemination and accessibility. Radios and televisions are popular sources of climate knowledge in the district. Farmers who have access to these types of information sources are far more likely to be aware of climate change than those who do not. Farmers' knowledge of climate change is also linked to their agricultural experience, which grows as their farming experience grows [18]. Farmers who have been working for a long time become more aware of variations in climate conditions. Similarly, through built information and resources, institutional access, whether private or governmental, affects farmers' understanding of climate change [18]. Climate change understanding is also aided by education and knowledge seeking behaviors [19]. 


\section{Climate change awareness amongst farmers}

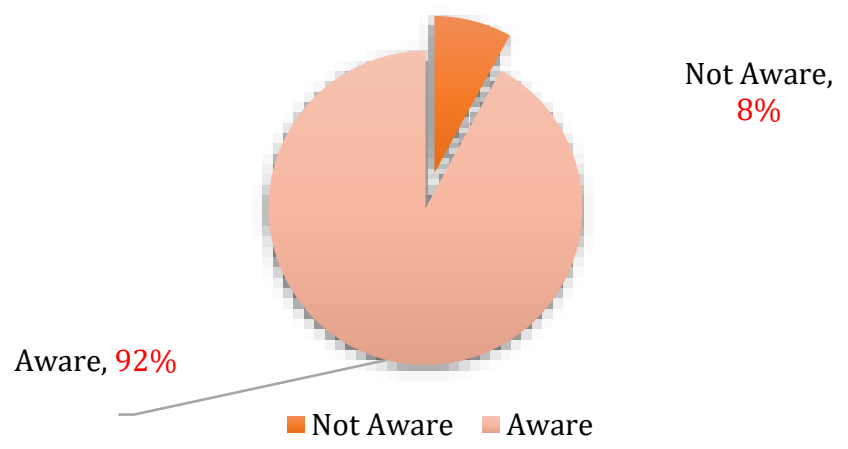

FIGURE 2: Farmers' awareness of climate change

\section{Farmers' experiences of climate change}

Farmers, as food producers, have been hit the hardest by climate change. They believe that rainfall patterns have shifted and have become more irregular and unstable [20] Farmers' ability to manage parasitic weed growth has been harmed as a result of changing rainfall patterns, which has ramifications for maize production [21]. Farmers believe that the timing of rainfall has improved, with rains arriving later than ever, the time of rainfall has decreased (as opposed to before when it rained from planting to harvest), and the rainy season has ended one or two months earlier than before [22]. According to farmers, climate change has led to crops drying before maturity, and they get damaged due to water shortage [23].

Farmers say that the weather has been hotter than before the hot season is now longer than one month, temperatures are increasing, heat has become intense, and that the hot season has become erratic [24].
Seasonal farming, in which rainfall and temperature determine productivity, is a risky practice that has been exacerbated by climate change [25]. Farmers must make choices in this situation on the adaptations they can make to mitigate the impacts of climate change. Climate change effects are being monitored and it is only where the threats are recognized that effective adaptation measures can be taken [26].

\footnotetext{
- Observation of farmers on temperature and rainfall in Leribe

When farmers in Leribe were questioned about their observations on temperature and rainfall trends, they admitted that temperatures have risen to high levels, while rainfall duration, intensity, and frequency have decreased. The responses of farmers are depicted graphically in Figure 3 below.
}

\section{Perceptions of farmers on temperature changes, rainfall duration, frequency and} intensity

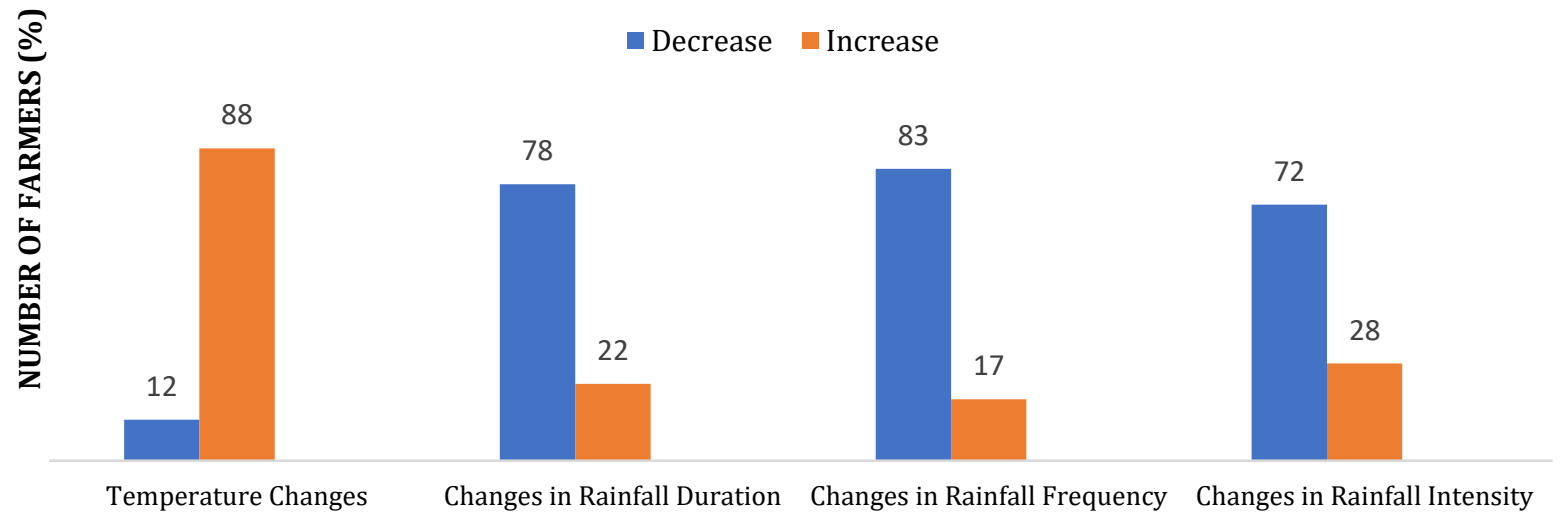

PERCEPTIONS OF FARMERS

FIGURE 3: Observation of farmers on temperature, rainfall duration, frequency, and intensity

Climate change has triggered extreme increases in temperature and has contributed to a reduction in rainfall period, frequency, and severity, according to $88 \%, 78 \%$, $83 \%$, and $72 \%$ of respondents. The views of these farmers are backed up by Lesotho Meteorological Services, which confirmed that the country had a bad start in October 2018, with unusually low rainfall in the lowlands. This suggests that rainfall in Leribe district, one of Lesotho's former food basket districts, has decreased [27]. Their perspectives are close to those of farmers in a study conducted in Kenya, where farmers reported extreme temperatures.
More than $70 \%$ of farmers in this region have outlined that high temperatures have prevailed in humid areas both during the day and at night [28]. According to a report conducted in Thaba-Nchu, South Africa, the temperature has been extreme [29]. Farmers in this region have also claimed that rainfall is insufficient, and that it rains suddenly because rains used to begin in September, but now begin in October, November, or December [29]. Similarly, $75 \%$ of Ethiopian farmers believe that temperatures have increased and $77 \%$ believe that rainfall trends have declined [30]. 


\section{RESPONDING TO CLIMATE CHANGE: ADAPTATION}

Unpredictable rainfall and temperature fluctuations have influenced water supply in general: water sources dry up during the dry season. Harvest is limited during the dry season, which is a major issue for farmers because there is little fertility or moisture in the soil, and nothing can grow [31]. Farmers have been forced to take spontaneous actions to mitigate the threats faced by climate change as a result of these factors.
Changes in planting and harvest times, crop rotations, crop variety and crop varieties for planting, water use for irrigation, and fertilizer use are all examples of farm-level adaptation steps [32]. When unreliable rainfall and high temperatures combine with restrictions that hinder access to climate change adaptation, crop losses are likely to be serious [26]. Crop hybrids, mixed cropping, cover cropping, tree shade, crop rotation, and fertilizer usage are among the techniques used by farmers in Leribe to mitigate the effect of climate change on agricultural production as shown in the Figure 4 below.

\section{ADAPTATION MEASURES PRACTICED}

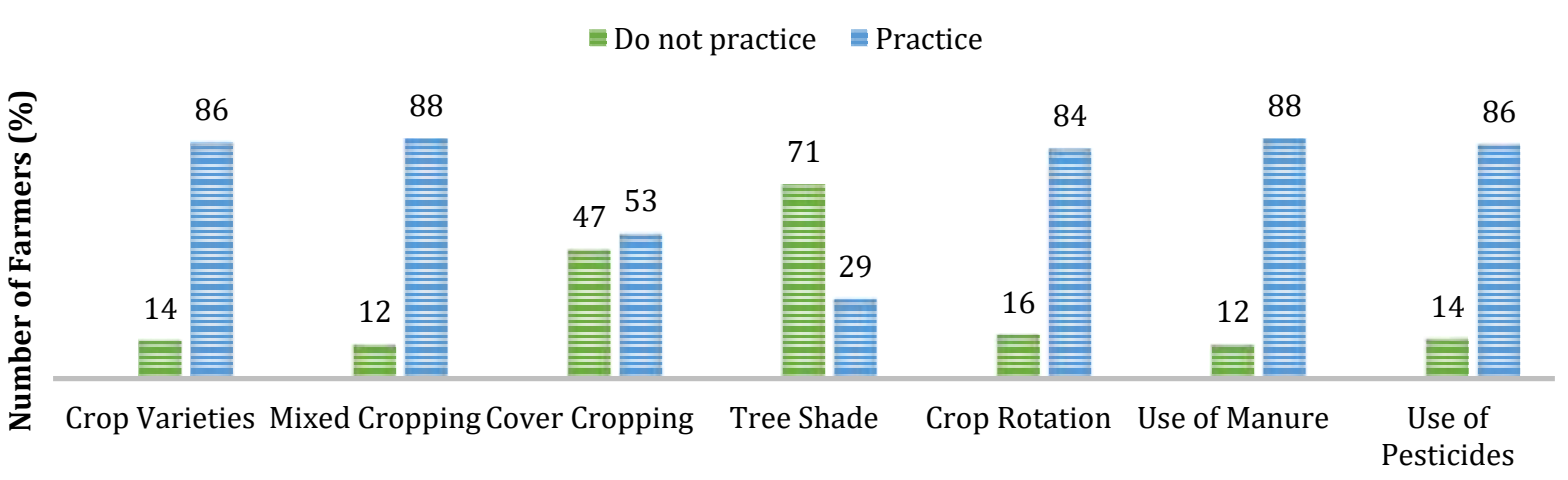

\section{Adaptation measures}

FIGURE 4: Adaptation measures practiced in Leribe

\section{Barriers to climate change adaptation}

Farmers say certain factors are preventing them from adapting to climate change, even if they want to do so. Barriers to climate change adaptation are obstacles that make planning and implementing adaptation measures more difficult or limit climate change adaptation choices [33]. Farmers in Leribe cite a shortage of climate knowledge, water for irrigation, financing, government funding, and education as some of the reasons that make adaptation actions more difficult to enforce. As seen in FIGURE 5, many farmers see these variables as barriers.

\section{- Lack of climate information}

Lack of climate information is a factor in the uncertainty in climate projections and models [34]. That is often due to a disconnect between the availability and demand of scientific information, where supply is dictated by the use of this information in achieving social goals, and demand is determined by the expertise and information generated by scientists $[35,36]$.
When asked what obstacles they face in adopting adaptation strategies, $82 \%$ of farmers in Leribe cited a shortage of climate data as one of them. Their statements are in line with the findings of a study conducted in Lesotho, which revealed that farmers primarily obtain climate information through radios. This, however, becomes a limitation because farmers do not always have access to radios, particularly when their batteries run out. Another impediment is when farmers do not understand what the details means and cannot ask clarifying questions [37]. Another study found that many farmers in Lesotho who depend on subsistence farming do not receive climate forecasts [38]. Climate data in Lesotho can help with agricultural decisions such as farming and livestock management, as well as provide an idea of how unpredictable temperatures and rainfall can be [39].

\section{Farmers barriers to climate change adaptation}
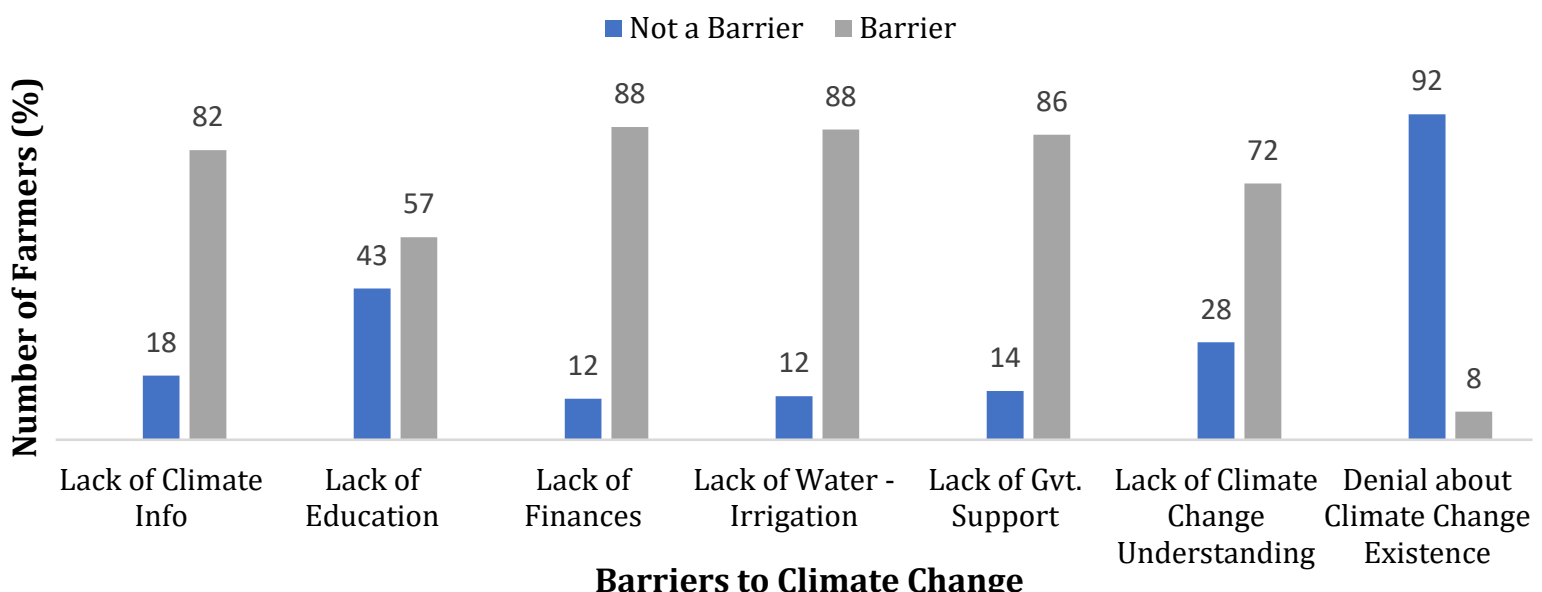

FIGURE 5: Barriers to climate change adaptation 


\section{- Lack of financial resources}

Lack of financial support includes a lack of funding to invest in adaptation mechanisms as well as the labor resources needed to respond to climate change [40]. Even though International Fund for Agricultural Development (IFAD) loans help Lesotho farmers maintain food security for their households, increase their incomes, and boost overall nutrition, 88 percent of farmers in Leribe believe that a shortage of financial capital prevents them from responding to climate change. Their viewpoints are influenced by the country's non-operational institutions, such as credit unions, as well as restricted access to bank loans and credit. A research in Lesotho found that farmers' revenue from non-farm operations is insufficient to fulfill borrowers' loan commitments, confirming the assumption that lack of financial capital is an obstacle to climate change adaptation. Farmers do not have access to structured finance because they are unaware of those institutions, lack collateral, and cannot afford the financial institutions high interest rates [41].

This viewpoint is similar to that of farmers in Bangladesh, where this factor was rated high as a problem by 55 percent and a medium problem by 44 percent of those interviewed [42]. Farmers' access to capital makes it simple to buy land and farm equipment, particularly for farmers who use irrigation [43]. Limited adaptation due to a shortage of financial means is consistent with the idea that developing countries are more vulnerable to the impacts of climate change than developed countries [44].

\section{- Lack of education}

Farmers who have access to education can use the information to adapt their management practices to changing climatic conditions [45]. When asked about the reasons that have prevented them from successfully responding to climate change, $57 \%$ of farmers cited a lack of schooling as one of the barriers. Concerns that climate information is not transmitted in a local language, and farmers who have not furthered their education find it difficult to comprehend the provided information, may be a barrier in this region. Similarly, climate change as a scientific term can be difficult to convert into a dialect that farmers may understand. Education plays a role in climate change adaptation because it improves farmers' capacity to access and implement relevant knowledge, thus expanding farm-level adaptation choices [46]. Education also increases the likelihood of responding to climate change even further. Education improved soil protection and shifting planting dates as adaptation approaches by $1 \%$ and $0.6 \%$ in the Nile Basin of Ethiopia, respectively [47]. If potential agricultural productivity decline is to be prevented, these conditions that farmers in Leribe consider as obstacles to their adaptation implementation must be tackled at both the local and national level.

\section{CONCLUSION}

Rainfed agriculture is normal in Leribe, as it is in most of Africa. Farmers cultivate crops for subsistence consumption in this area. Climate change, on the other hand, has had a negative effect on the productivity and yields of these important crops. Farmers are mindful of climate change, and their observations mostly include higher temperatures and reduced rainfall period, severity, and frequency. Changes in these climate conditions have had a negative effect on crop production. As a result, farmers have had to use a variety of techniques to mitigate the effects of climate change, including seed hybrids, mixed cropping, crop rotation, and cover cropping, among others. Farmers can improve their adaptation to climate change, but they see obstacles such as inadequate access to climate information, lack of financial resources and lack of education among others as preventing them from doing so.
Lesotho should use early warning technologies for extreme weather and climate disasters to reduce and mitigate risks to overcome the lack of climate awareness obstacle. Seasonal forecasts and early warning systems are important for adaptive climate risk management because the knowledge provided by these systems will help farmers respond to climate change and make timely decisions. Lesotho's government and development partners can channel access to up-to-date weather information. This could assist farmers in making decisions and sharing knowledge in order to adapt. Lesotho could require the creation of training centers and hire agricultural agents with experience in farming materials and equipment in its policies to address the shortage of farmer education. These experts will be able to offer continuing capacity-building assistance to farmers and agricultural extension officers. Lesotho must create farm field schools to implement the adaptation practices (FSS). The aim of FSSs will be to improve farmers' awareness of processes that influence their crop and livestock production. Farmers will be able to make their own locally relevant crop management decisions using the information gained from FSS's. The government must promote agricultural research and production, as well as disseminate relevant technology.

Conflict of interest

Authors declare no conflict of interest.

\section{REFERENCES}

[1] Adebayo, A.A., Onu, J.I., Adebayo, E.F. and Anyanwu, S.O., Farmers' awareness, vulnerability and adaptation to climate change in Adamawa State, Nigeria. British journal of arts and social sciences, 2012. 9(2): p. 104-115.

[2] Gwimbi, P., Thomas, T.S., Hachigonta, S. and Sibanda, L.M., Lesotho. 2013, IFPRI.

[3] Nations), F.F.a.A.O.o.t.U., Assessment of 2005/06 Agricultural Production in Lesotho: Available at: www.sadc.int/fanr/aims/rvaa/Documents/Lesotho/ 2006\%20Lesotho\%202006\%20Agricultural\%20Seas on\%20Assessment.pdf. 2010.

[4] Owusu-Ampomah, K., Naysmith, S \& Rubincam, C., Reviewing "emergencies" in HIV and AIDS-affected countries in Southern Africa: Shifting the paradigm in Lesotho. National AIDS Commission, Lesotho and Health Economics and HIV/AIDS Research Division (HEARD), University of KwaZulu-Natal, 2009.

[5] Thobei, S., Komariah., Effects of Climate Change on Crop Production in Thaba-Tseka and Mokhotlong Districts Lesotho Highlands. Journal of Agriculture and Veterinary Science, 2014. 7(1): p. 37-44.

[6] UNEP, Climate change, climate and variability in Southern Africa: Impacts and adaptation in the agricultural sector: Available at: http://apps.worldagroforestry.org/downloads/Publicatio ns/PDFS/B14549.pdf. 2006.

[7] Wheeler, T.R., Craufurd, P.Q., Ellis, R.H., Porter, J.R. and Prasad, P.V., Temperature variability and the yield of annual crops. Agriculture, Ecosystems \& Environment, 2000. 82(1-3): p. 159-167.

[8] Services., L.M., Lesotho's Mitigation Contribution. 2018.

[9] committee, L.v.a., Market Assessment Report. 2016 
[10] Pheko, M., Agriculture and Food Security Statistics[online]. Retrieved from: http//www.bos.gov.ls/Agric_livestock.htm. . 2004.

[11] MDAT, Rapid Drought Impact Assessment Report[online] Retrieved from: http//www.undp.org/content/dam/unct/Lesotho/doc s/humanitarian\%20efforts/Programmes\%2 0cycle/MDAT\%20Rapid\%20Impact\%20Assessment\%2 OReport\%20-\%. 2016.

[12] Mekbib, S.B., Olaleye, A., Mokhothu, M.N., Tilai, S.B., Wondimu, T. and Johane, M., Assessment of the impacts and adaptive capacity of the Machobane Farming System to climate change in Lesotho. 2012.

[13] Statistics, L.B.o., 'Lesotho Census 2016 - Summary of Key Findings'. Availbale at: http://www.bos.gov.ls/2016\%20Summary\%20Key\% 20Findings.pdf. 2018.

[14] Palinkas, L., A., Horwitz, S. M., Green C., A., Wisdom, J. P., Duan. N, and Hoagwood., K., "Purposeful sampling for qualitative data collection and analysis in mixed method implementation research.". Administration and policy in mental health and mental health services research 2015. 42(5): p. 533-544.

[15] Cohen, L., Manion, L. and Morrison, K., Observation. Research methods in education., 2007. 6(396-412).

[16] Sarantakos, S., “Social Research”. 3rd ed ed. 2005.

[17] Falaki, A.A., Akangbe, J.A. and Ayinde, O.E., Analysis of climate change and rural farmers' perception in North Central Nigeria. Journal of Human Ecology, 2013. 43(2): p. 133-140.

[18] Mustafa, G., Latif, I.A., Bashir, M.K., Shamsudin, M.N and Daud, W.M.N.W., Determinants of farmers' awareness of climate change. Applied Environmental Education \& Communication, 2019. 18(3): p. 219-233.

[19] Raghuvanshi, R.a.A., M.A., A study offarmers'awareness about climate change and adaptation practices in India. Young (Less than 45), 2017. 45(40-90).

[20] Jennings, S.M., J., What happened to the seasons., F.A.C.I. Conference on Seasonality, Editor. 2009: Sussex, UK. p. 1-28.

[21] Stringer, L.C., Twyman, C. and Thomas, D.S, Combating land degradation through participatory means: the case of Swaziland. AMBIO: A Journal of the Human Environment, 2007. 36(5): p. 387-393.

[22] Simelton, E., Quinn, C.H., Batisani, N., Dougill, A.J., Dyer, J.C., Fraser, E.D., Mkwambisi, D., Sallu, S. and Stringer, L.C., Is rainfall really changing? Farmers' perceptions, meteorological data, and policy implications. Climate and development, 2013. 5(2): p. 123-138.

[23] Mkwambisi, D.D., Gomani, M.C., \& Kambani, C., Assessing the impact of climate change on agriculture and rural livelihoods in Malawi. 2010.

[24] Yaro, J.A., The perception of and adaptation to climate variability/change in Ghana by small-scale and commercial farmers. Regional Environmental Change, 2013. 13(6): p. 1259-1272.
[25] Rao, K.P.C., Ndegwa, W.G., Kizito, K. and Oyoo, A., Climate variability and change: Farmer perceptions and understanding of intra-seasonal variability in rainfall and associated risk in semi-arid Kenya. Experimental agriculture, 2011. 47(2): p. 267-291.

[26] Osbahr, H., Dorward, P., Stern, R. and Cooper, S., Supporting agricultural innovation in Uganda to respond to climate risk: linking climate change and variability with farmer perceptions. . Experimental agriculture, 2011.47(2): p. 293-316.

[27] Morahanye, M., Role of Non-Governmental Organizations (NGOS) in climate change adaptation and mitigation strategies: a case study on Leribe district, Lesotho., in Faculty of Economics and Management Sciences. 2020, University of the Free State. p. 98

[28] Chepkoech, W., Mungai, N.W., Stöber, S., Bett, H.K. and Lotze-Campen, H., Farmers' perspectives. International Journal of climate change strategies and management, 2018.

[29] Gandure, S., Walker, S. and Botha, J.J., Farmers' perceptions of adaptation to climate change and water in a South African rural community. . Environment Development., 2012.

[30] Habtemariam, L.T., Gandorfer, M., Kassa, G.A. and Heissenhuber, A., Factors influencing smallholder farmers' climate change perceptions: a study from farmers in Ethiopia. Environmental management, 2016. 58(2): p. 343-358.

[31] Slegers, M.F., "If only it would rain": Farmers' perceptions of rainfall and drought in semi-arid central Tanzania. Journal of Arid Environments, 2008. 72(11): p. 2106-2123.

[32] Rosenberg, N.J., Adaptation of agriculture to climate change. . Climatic change., 1992. 21(4): p. 385-405.

[33] Eisenack, K., Moser, S.C., Hoffmann, E., Klein, R.J., Oberlack, C., Pechan, A., Rotter, M. and Termeer, C.J., Explaining and overcoming barriers to climate change adaptation. Nature Climate Change, 2014. 4(10): p. 867-872.

[34] Antwi-Agyei, P., Stringer, L.C. and Dougill, A.J., Livelihood adaptations to climate variability: insights from farming households in Ghana. Regional environmental change, 2014. 14(4): p. 1615-1626.

[35] Dilling, L.a.L., M.C., Creating usable science: Opportunities and constraints for climate knowledge use and their implications for science policy. . Global environmental change, 2011. 21(2): p. 680-689.

[36] Pielke, R., Prins, G., Rayner, S. and Sarewitz, D., Lifting the taboo on adaptation. Nature, 2007. 445(7128): p. .597-598.

[37] Ziervogel, G., Targeting seasonal climate forecasts for integration into household level decisions: the case of smallholder farmers in Lesotho. Geographical Journal, 2004.170(1): p. .6-21.

[38] Ziervogel, G.a.C., R., Climate variability and rural livelihoods: assessing the impact of seasonal climate forecasts in Lesotho. Area, 2003. 35(4): p. 403-417. 
[39] Marshall G R, P.K.A.a.H.G., L., Risk attitude, planting conditions and the value of seasonal forecasts to a dryland wheat grower. Australian Journal of Agricultural Economics 1996. 40 p. 211-33.

[40] Sanga, G.J., Moshi, A.B. and Hella, J.P., Small scale farmers' adaptation to climate change effects in Pangani River Basin and Pemba: challenges and opportunities. 2013.

[41] Motsoari, C., Access to credit and agricultural production in Lesotho. 2012, University of the Free State. p. 1-151.

[42] Uddin, M.N., Bokelmann, W. and Entsminger, J.S., Factors affecting farmers' adaptation strategies to environmental degradation and climate change effects: A farm level study in Bangladesh. Climate, 2014. 2(4): p. 223-241.
[43] Tangonyire, D.F.a.A., G.A., Socioeconomic factors influencing farmers' specific adaptive strategies to climate change in Talensi district of the Upper East Region of Ghana. Ecofeminism and Climate Change., 2020 .

[44] Maddison, D., The perception of and adaptation to climate change in Africa. 2007.

[45] Tizale, C.Y., The dynamics of soil degradation and incentives for optimal management in the Central Highlands of Ethiopia, in Department of Agricultural Economics, Extension and Rural Development. 2007, University of Pretoria. p. 1-112.

[46] Gebrehiwot, T.a.V.D.V., A., Farm level adaptation to climate change: the case of farmer's in the Ethiopian Highlands. Environmental management, 2013.52(1): p. 29-44.

[47] Deressa, T.T.a.H., R.M., Economic impact of climate change on crop production in Ethiopia: Evidence from cross-section measures. Journal of African economies, 2009. 18(4): p. 529-554. 